\title{
Intangible cultural heritage and sustainable development in the Douro Demarcated Region (Northern Portugal): the cases of Cambres and Parada do Bispo
}

O património cultural imaterial e o desenvolvimento sustentável da Região

Demarcada do Douro (NE de Portugal): os casos de Cambres e Parada do Bispo

Le patrimoine culturel immatériel et le développement durable dans la Région Viticole du Douro (NE de Portugal): les cas de Cambres et Parada do Bispo

El patrimonio cultural inmaterial y el desarrollo sostenible de la Región Demarcada de Douro (noreste de portugal): los casos de Cambres y Parada do Bispo

\section{Helena Pina}

\section{OpenEdition}

Journals

\section{Electronic version}

URL: http://journals.openedition.org/espacoeconomia/2100

DOI: 10.4000/espacoeconomia.2100

ISSN: 2317-7837

\section{Publisher}

Núcleo de Pesquisa Espaço \& Economia

\section{Electronic reference}

Helena Pina, « Intangible cultural heritage and sustainable development in the Douro Demarcated Region (Northern Portugal): the cases of Cambres and Parada do Bispo », Espaço e Economia [Online], 7 | 2015, Online since 14 April 2016, connection on 15 November 2019. URL : http:// journals.openedition.org/espacoeconomia/2100

This text was automatically generated on 15 November 2019.

(C) NUPEE 


\title{
Intangible cultural heritage and sustainable development in the Douro Demarcated Region (Northern Portugal): the cases of Cambres and Parada do Bispo
}

\author{
O património cultural imaterial e o desenvolvimento sustentável da Região \\ Demarcada do Douro (NE de Portugal): os casos de Cambres e Parada do Bispo \\ Le patrimoine culturel immatériel et le développement durable dans la Région \\ Viticole du Douro (NE de Portugal): les cas de Cambres et Parada do Bispo \\ El patrimonio cultural inmaterial y el desarrollo sostenible de la Región \\ Demarcada de Douro (noreste de portugal): los casos de Cambres y Parada do \\ Bispo
}

Helena Pina

\section{Introduction}

1 Although consumed by many problems (environmental, economic, social, cultural) the very diverse rural world has nonetheless great potential and characteristics that need to be stimulated. This is particularly true in the case of the Douro Demarcated Region (DDR), partially classified by UNESCO as World Heritage, as a tribute to the centuries-old work carried out by Man, creating a striking landscape characterized by a superb architectural, cultural, social and oenological heritage. Population and economic progress is, however, limited, featuring aged and declining social structures, which is why the endogenous resources must be preserved and valued, catalysing all intervening agents, while it still has all its virtues. This is the only way to revive and sustainably develop this region. It is in this context that the symbolic and religious heritage fits into, for instance, festivities 
and processions. Although intrinsically religious, these festivities are also social, cultural, economic, and tourist events, and are an inestimable help to better understand the collective past and to enhance the development of these spaces in a sustainable and systemic way.

But what is sustainable development? While economic development has often gone hand in hand with environmental deterioration (MARMUREANU et al., 2011; OLIVEIRA, 2012) and lack of social cohesion and equality, we need to change this state of things by introducing an integrated management of the territory, creating new sustainability alternatives spanning the major issues of environment and preservation of biodiversity, or endogenous resources. But if this is to happen, all social agents must be involved and motivated towards sustainable change processes, which in turn requires an innovative collective culture and finding flexible solutions to solve the problems. This also includes the cultural and heritage aspects.

3 The development of rural resources is a complex process. These resources are undervalued, even though they form $92 \%$ of the EU territory. Many different players with contradictory roles intersect in these areas (WOODS, 2005; CLOKE, 2006; FERNANDES, 2010; CLAVAL, 2012). Indeed, while there are many solutions to render them more modern (MAXWELL et al., 2001; BOTELHO, 2013), they can sometimes put their sustainability on the line. So, even though Woods (2005) values the characteristics of the landscape and the human element, both the resident and the occasional tourist, and also the built heritage and its function, the scenario is still complex and diversified (PINA, 2014; OLIVEIRA, 2012). In fact, since rural societies are based on a poorly dynamic sociocultural framework, yet changing constantly, especially due to the interference of media and the more modern and innovative urban culture, if these specificities were not preserved, this could lead to standardization, to a loss of identity (WOODS, 2005). So, we need to develop but also preserve the distinctive values of rural spaces, a reflection of local culture and experiences, failing which identity would be lost. Moreover, although rural spaces are often regarded as inferior (BLUME, 2004), if new technologies were to be taken up indiscriminately - albeit critical to modernization -, there would also be social and cultural changes because social processes are essential and reflect all changes (BLUME, 2004; OLIVEIRA, 2012).

4 Furthermore, as about $92 \%$ of the EU territory is considered rural or predominantly rural, and home to about $56 \%$ of the population (in Portugal the numbers rise to $92.7 \%$ - GPPAA, 2005), these rural areas are a constant presence, a strategic asset for regional development (BLUME, 2004), yet diversity and social dynamics are unavoidable (TERLUIM, et al., 2010). So the European space is not only characterized by recession and demographic decline, but also drive and innovation, with signs of a distinct, sustainable development (SILVA, 2010; BOTELHO, 2013). This would be the answer to the challenges posed by Horizon 2020, provided there is cohesion between local actors, co-operating in networks with other regional and sectorial bodies (TERLUIM et al., 2010).

In Portugal, INE (2009) classifies the regions into three groups: "predominantly rural", "intermediate" and "predominantly urban". The DDR is considered as predominantly rural, and city councils as "intermediate", and occasionally "urban", as in the case of Peso da Régua, Lamego and Vila Real.

6 As rural landscapes represent a balance between natural characteristics and human activities, in addition to being a physical and environmental protection space, they are, 
above all, a social and cultural space. Moreover, since the 1980s we speak more of "nonagricultural rural", which provides new multifaceted readings of these spaces. Although these spaces were markedly agricultural until the early 1990s (productivist model, enhanced by the Common Agricultural Policy), they have undergone profound changes and began to be discussed in a multifunctional approach (CASTRO, 2014), which values a non-productive dimension of the rural aspect, building on the idea of social and heritage (PINA, 2011). It is therefore an investment in renaturalisation (nature conservation and protection - KLAUCO et al., 2012), but also in the search for authenticity that favours the conservation and protection of historical and cultural heritage; this is how memories and identities are valued, as well as the commercialisation/legacy of landscapes, in response to new consumption patterns (FERNANDES, 2013); this is also how the multiple occupations and multiple income of farming families are highlighted (PINA, 2013), giving rise to a real, multifaceted territorial mosaic, yet with places of excellence to be explored in terms of sustainable development.

7 We will only be able to understand the Portuguese and European rural areas beyond the inter-relation between urban and rural (CLAVAL, 2012), if we value multifunctional approaches and have a broad perspective (VALLINA, 2002), which will lead to the implementation of new Rural Development Policies. We must, of course, also remember the small and medium hinterland cities and their pivotal role, their challenging facet in regional terms. In addition to these changes, there is also the environmental awareness resulting from the many environmental problems societies are facing today, the relevance of social identity and the connection between nature and the rural setting, and the value of authenticity, built heritage, local culture (PINA, 2014). It is in this context that these spaces are meant to be developed globally, assigning new roles to the farmer in terms of environmental, landscape, and cultural preservation, the supporting pillars of local development and regional planning.

8 By playing a pivotal role, as a pull factor of other activities taking place in rural areas, the agricultural sector therefore offers benefits to the local community and the environment, minimizing the negative impacts of pollution, erosion, and the loss of biodiversity (MARMUREANU et al., 2011). Nature, the landscape, handicrafts, and other traditional arts and crafts will thus be preserved, while at the same time tourism and leisure are integrated (CASTRO, 2014), bringing about innovation; this is the multifaceted approach to a territory (KLAUCO et al., 2012), with a view to its planning and sustainable development (PINA, 2012, 2013).

"Future rural development is either sustainable or it is not development at all." (VALLINA, 2002, p. 20). It is in this context that we also give priority to the preservation of heritage, including cultural and intangible heritage, as we try to overcome the demographic and economic decline of rural areas (PINA, 2007, 2009). This is the only way to achieve sustainable development, expanding and emphasising agricultural practices in line with the new social and cultural roles of rural areas. In this respect, what is the role of intangible culture, of traditional and religious festivities?

Before we begin, we need to point out that traditional festivities revive experiences because while they honour their patron saint, they ultimately encourage territorial dynamics. These are intense moments for the locals and for this more or less vast area, providing an opportunity for reuniting those that have embarked on the Diaspora (PINA, 2007, 2014). It is in this context that we will examine two parishes of the Lamego council (Cambres and Parada do Bispo- Fig. 1). The landscapes of these rural areas are privileged 
yet distinct, and are situated in the DDR, closed to two multifunctional urban centres of great regional relevance, Lamego and Peso da Régua. Although they benefit from good transport connections, especially after the A24 was opened the railway and waterway, the Douro River, there are nevertheless barriers to their development, such as demographic decline and the structural aging of the local population. Moreover, the economic fabric is also deteriorating (PINA, 2013). To develop this territory, the strategy was to invest in the multifunctional potential of the landscape, in tourism, yet minimising aspects likely to expand local dynamics, such as built, cultural, and intangible heritage.

Both parishes part of our study (Cambres and Parada do Bispo) hold festivities dedicated to their patron saints, held in the summer, and have century-old backgrounds inseparable from the local economic drive, formed by the vines. In Parada do Bispo we also find the "marrã", bisaro pig's meat with special organoleptic qualities. Moreover, whereas in the early $21^{\text {st }}$ century priority was given to urban centres and their merry festivities, in the rural areas we often find chapels much in need of maintenance, as the events that helped maintain the cult in them became scarcer, until they almost disappeared. Now, only the most prominent ones still exist, such as those mentioned herein.

Fig. 1. The Douro Demarcated Region and the two parish, Cambres and Parada do Bispo

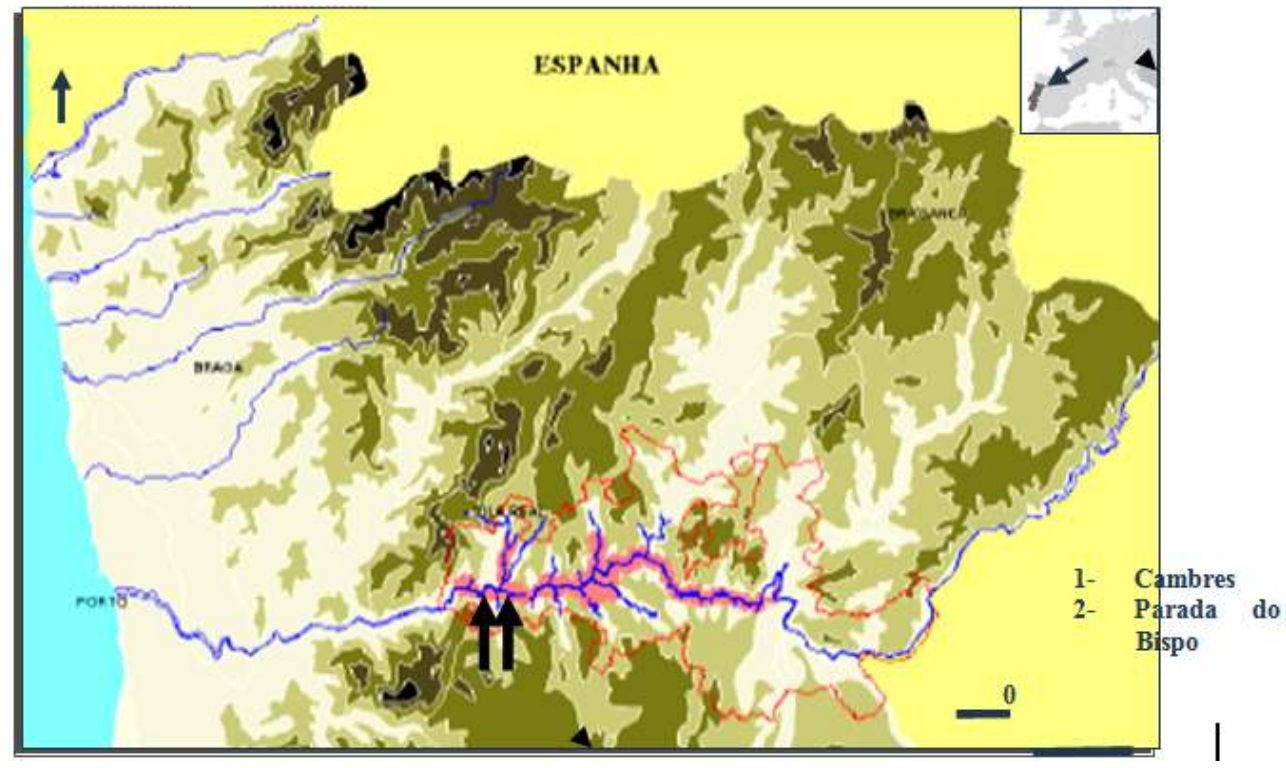

(Source: Plano Interm. De Orden. Territ. Do Alto Douro Vinhateiro, UTAD)

In an environment in which we are increasingly committed to sustainable development, the preservation of cultural, architectural, or landscape diversity is something we see as an imperative in societies today, to preserve its local identity. This is the context in which UNESCO, through various conventions, promotes the preservation and revitalisation of "the world's superb natural and scenic areas and historic sites for the present and the future of the entire world citizenry" (UNESCO, 1978), which, for example, happened to a significant part of the DDR in 2001, illustrating a century-old human intervention that created a wine-growing landscape in terraces. Yet the intangible side of heritage had to be preserved, which is why the first convention appeared in 2003 for the safeguarding of intangible cultural heritage, defining in its Article 2 that it means "the practices, representations, expressions, knowledge, skills - as well as the instruments, objects, 
artefacts and cultural spaces associated therewith - that communities, groups and, in some cases, individuals recognize as part of their cultural heritage. This intangible cultural heritage, transmitted from generation to generation, is constantly recreated by communities and groups in response to their environment, their interaction with nature and their history, and provides them with a sense of identity and continuity, thus promoting respect for cultural diversity and human creativity" (UNESCO, 2003). The safeguarding of this heritage is thus proposed, ensuring the feasibility of this intangible cultural heritage, as well as its preservation, protection and promotion. In recent years, following the 2005 Convention, and with a view to a sustainable, holistic and distinctive development, UNESCO has also encouraged cultural and policy-makers to implement this. This is how the "Decade of Education for Sustainable Development - 2005/14" came to the fore.

13 In the current circumstances, it is therefore appropriate to question the impact of festivities and processions on rural areas. How do we harmonise culture, tradition, preservation and innovation to consistently drive these territories? It cannot be ignored that the landscape remains, but anchored in the activities carried out by the locals, to which occasionally the activities of other players - in general, economic players - are sometimes added.

\section{Methodology}

14 Knowing that the DDR heritage is recognised by UNESCO, we could not ignore the importance of intangible heritage, especially when talking about the sustainable development of these areas. In such circumstances, and given the exposure of these festivities in honour of local patron saints, we have chosen two cases in rural areas, in an attempt to detect not only the religious background of the festivities, but also their social and economic backgrounds.

15 To achieve this goal, our methodology combines a thorough analysis of extensive local and regional bibliography, given the theme in question, in addition to the study of various documents that refer to the organizational and economic characteristics of these festivities. We have also worked in an evolutionary perspective, beginning our study in the $19^{\text {th }}$ century and ending in 2014 .

Given the reputation of these festivities, one of which dates back to the $19^{\text {th }}$ century (Senhor da Aflição) and the other is centuries-old (Santa Eufémia), we obviously had to conduct extensive research in public and private archives, in particular in the District Archive of Viseu, the archive of the Sisterhood of Nosso Senhor de Aflição, and even in the Archive of the Diocese of Lamego, among others. Some of these documents are handwritten and cover a long period of time, from the $18^{\text {th }}$ century to today. Moreover, as our plan was to also determine the impact of these festivities through the spending and revenue involved, and for that we based our research on the book "Livros de despesas da Irmandade do Senhor da Aflição" and on manuscripts, part of which is kept at the District Archive of Viseu, particularly those from the $19^{\text {th }}$ century.

17 This essential information would nevertheless need to be supplemented by other information in newspapers, which is more up-to-date, varied, and covers many themes depending on the authoring journalist. So, to the archive information we have added the analysis of regional newspapers such as "O Jornal da Regoa" (1880-1893), published in the 
neighbouring Régua council, but especially news from newspapers published in the Lamego council where the parishes are found, as is the case of "A Semana" (1900-1909), "A Esperança" (1909/10), “A Fraternidade" (1930-48), “A Varanda do Douro" (1950-95) and "A Voz de Lamego" (1935-2013). We also examined two national newspapers, published in Porto, "O Jornal de Notícias" and "O Primeiro de Janeiro". Our main concern was to focus on the months closest to the festivities (October/November and June/ August) and on the years that best represented the local and regional dynamics and problems that influenced the festivities and their reputation. We thus confirmed the prominence of Senhor da Aflição, as references keep pointing to its surrounding landscapes and accessibilities, in addition to the highlights of the festivities and the diversity of attractions. There is also news of social and economic interest, deliberately linking the festivities with their dissemination, as in the case of the introduction of electric power, the cattle fairs, and the paved roads, in addition to the diversity, innovation and quality of the festivities, interconnected with the social and wine industry contexts at the time.

Having in mind the sustainable development of the parishes concerned, we complemented our documentary research with the analysis of the current impact of these festivities and the extent of the population's support. We have therefore combined the analysis of statistics provided by the National Statistics Institute in the Agricultural Censuses (1989, 1999 and 2009) and Population Censuses (1900 to 2011), carrying out interviews and surveys between 2012 and 2014, focusing in particular on the period of festivities, during which we conducted a series of interviews to the persons responsible for organising them and traders, but especially (random) surveys to the residents, visitors and tourists. These surveys were administered on the various days of the events, and at different times, which was the only way to contact with the various social and age groups, who clearly had different motivations and cultural and musical preferences. In the case of Santa Eufémia, we covered both festivities periods, 1 November and the last Sunday of August.

Through these surveys/interviews we found the profile of both the event organizers and of residents and tourists, and how aware they are of the importance and quality of these events. We have attached their opinion on the opportunity/quality of events held today to our work, according to various parameters (landscape, economic, social and cultural), and conclude by raising a question on the future - the continuity of these festivities. With a few rare exceptions, mentioned in the text, the opinion is rather positive, regardless of how the topic is addressed and the type of interviewees.

This methodology allowed us to conclude this work, addressing illustrative cases of festivities still found in rural areas, and their implications in the sustainability of these spaces. 


\section{Intangible Heritage, a component of sustainable development}

\section{Senhor da aflição (Cambres) and its impact}

\section{Brief background of the parish}

21 The parish of Cambres is located in the Lamego council (NE Portugal - Fig. 1), spreading across $11.16 \mathrm{Km}^{2}$, between Lamego and Peso da Régua. It boasts an exceptional landscape with many traditional terraced vineyards, very tough to work in, but also terraces that have recently been restructured and mechanised, which is one of the ways of overcoming the shortage of workers and the high wages they earn. The parish is marked by a changing Mediterranean climate and a schist soil, forming a traditional landscape in which the vineyard is combined with other cultures, such as olive-trees, marking the boundaries of farming plots, and fruit trees (PINA, 2007), justifying the persistence of a clear landscape biodiversity with historical traditions (Photos 1 and 2).

Photo 1 - Partial views of Cambres parish

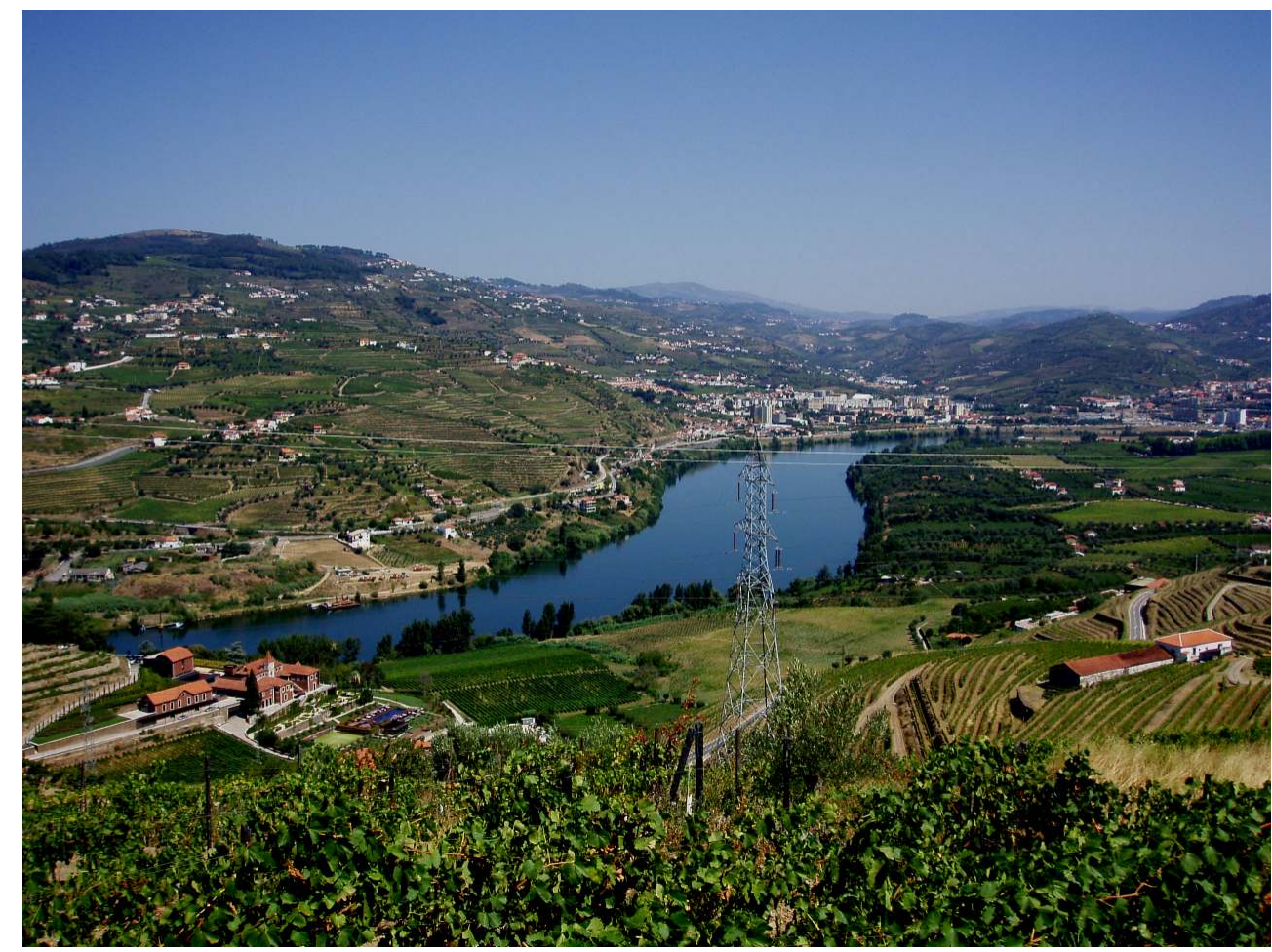

(Photos of the author May, 2013)

This scenario is also enhanced by the presence of scattered settlements and a magnificent architectural heritage, with many $17^{\text {th }}$ to $19^{\text {th }}$ century manor houses, in farms and inhabited places, evidence of human occupation that dates back in time, but especially examples of religious heritage from the $17^{\text {th }}$ and $18^{\text {th }}$ centuries (AZEVEDO, s/d; COSTA, 1999).

Despite the very appealing aspects mentioned above, Cambres has many problems, in particular those related to the wine sector. This activity goes back in time, as there is 
evidence that vineyards existed in Cambres as far back as in the 16th century (DIAS, 1947). This culture, however, expanded during the period of the Marquis of Pombal ( $18^{\text {th }}$ century), on terraces placed on the slopes. Today, however, there are many problems, notably the poor land structure, old vineyards, labour shortage, and its poor technical training, and also demographic decline (there were 3,290 residents in 1900, 4,675 in 1940, but only 2,066 residents were accounted for in 2011, i.e., $43.8 \%$ of the peak reached in 1940 ! - INE). This unquestionable trend since the 1960s mirrors the successive regional wine crises that induced large emigration flows, which is why today about $23 \%$ of residents are over 65 years of age, with a basic technical training level. Younger residents, with a different profile, often leave the parish (PINA, 2011, 2013).

Photo 2 - Cambres: sparsely populated and persistence of traditional biodiversity.

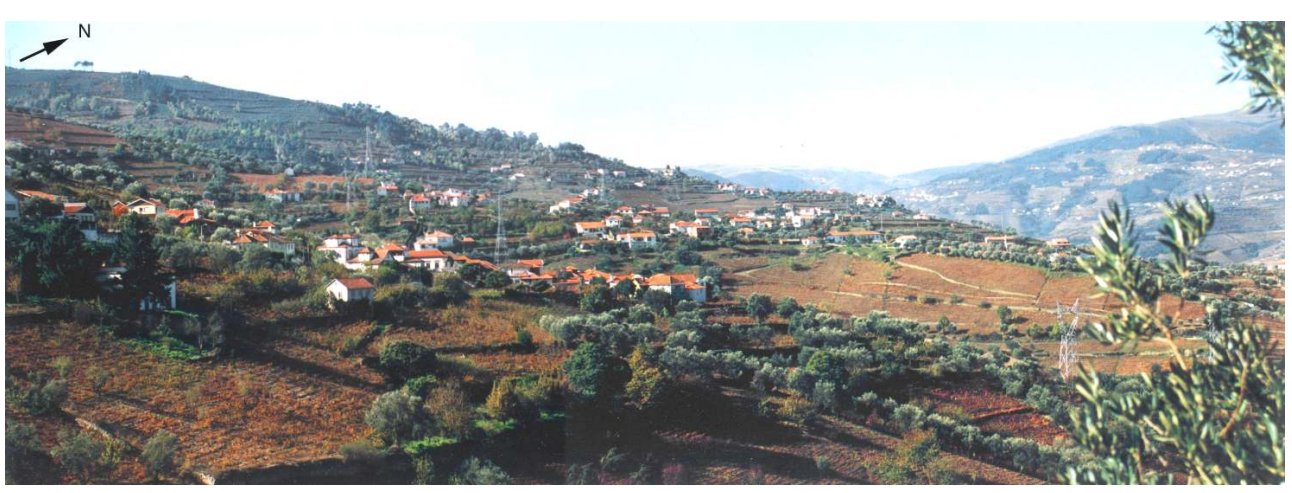

(Photo of author, May, 2013)

It is the wine sector, however, that supports the local economy, based on small familytype farms, as the average size of farmsteads was, in 2009, of about 4.8 hectares (INE). Moreover, $41.2 \%$ of these farms were less than 1 hectare. These small farm owners preserve the landscape and continue their wine farm work despite the low yield (Pina, 2013). In order to allow for a sustainable growth, vineyards need to be modernised restructured and farmers must receive technical training.

At the same time, this landscape has been upgraded through investments, especially in Tourism Rural Areas (TER). This activity appeared in the early 1980s, and consists of a type of lodging representing the rural and cultural identity of the region, set in buildings with typical architectures that mingle well in terms of culture and environment in the surrounding area.

This type of tourism is unconventional, has a family-type structure and is characterised by customised tourist accommodations, allowing guests to learn more about practices, values and traditions, namely the intangible traditions. This tourist activity is complemented by family-run Guest Houses and Wine Tourism, thus providing a sustainable multifunctional approach that values endogenous resources and adds to farming activities other activities that depend on and interact with them (handicrafts, entertainment, cultural and sports activities).

The expansion of the Rural Tourism became more noticeable after the Douro region was classified by UNESCO as "Evolving Living Landscape, World Heritage" (2001), and came to include average and large wine farms (PINA, 2011, 2012). Because seasonality is a reality, this activity is further complemented by other more conventional offers, such as hotels, which together help form a strategy to revive this region, favouring the preservation of 
landscape, wine culture, and social structures. But there is also intangible heritage, local festivities to enjoy.

\section{The festivities of Senhor da Aflição (Our Lord of Afflictions) and their impact}

Although subject to different interpretations, festivities and processions have always attracted the population, depending on their history, geographical location, accessibilities and, more recently, their dissemination and marketing. Nevertheless, they have decreased in number in rural areas, in comparison with the 1980s. Although there were some setbacks due to the world conflicts that forced the interruption of Port wine exports, the festivities continued because they were "major regional events (...) an opportunity for people from all over the province to come together" (VASCONCELOS, 1997, 302) and they preserved the "typical features of local cultures, customs and mores, folklore, and even handicrafts" (OLIVEIRA, 1984, 220). In short, festivities and processions were social events with a strong religious, economic and cultural influence.

Nowadays, however, these festivities are increasingly limited to major population centres, while in the rural areas where they still take place, especially in the more peripheral areas, the situation is getting worse. Nevertheless, Cambres still hold the festivities in honour of Senhor da Aflição. The first documented references to this popular festivity date back to the $19^{\text {th }}$ century, and it spread its influence not only to the neighbouring wine parishes, but also to the surrounding urban centres. After the "Ponte de Peões" bridged was inaugurated in 1872, linking the two Douro River banks, and the arrival of the railway in Régua in 1879 (PINA, 2007), this influenced spread also to Porto.

In the early 19th century, the Douro region experienced very difficult times which reflected the successive bad harvests and the sluggish wine exports, a situation which deteriorated even further with the widespread of fungal diseases, such as spot diseases, rust and powdery mildew, "inducing" epidemics of cholera and yellow fever (SOUSA, 2006). It was only in 1880 , however, when phylloxera devastated the vineyards in the region, in particular those in Parada do Bispo, and came closer to the Cambres vineyards that the residents found themselves powerless to overcome it, held a procession of repentance, "to implore divine protection against phylloxera" ("Jornal da Regoa", 10/07/1880, p.2). As their prayers were heard, references to Senhor da Aflição were advertised in the regional and national newspapers, announcing the famous festivities and informing about.

31 In the $20^{\text {th }}$ century, despite the adverse political, economic and social problems, especially those that prevented wines from being marketed due to world conflicts, and the growing social problems, the festivities were still held, because although the religious aspect was mostly valued, they had an important social and economic dimension. For example, in 1900 the procession was considered "onde of the most popular and famous processions in this region", consisting of 3 processions and "with many lights and fireworks, (...), easy access from this town (Lamego) and other towns nearby to the site of the procession" ("A Semana", 1900, 21 July). Public transportation was provided connecting with the surrounding urban centres and the city of Porto.

As time progressed, other "innovations" stressed the social dimension of the festivities: festivals that continued long into the night, musical entertainment by the bands, lights and fireworks, and the introduction of electricity in the parish (1909). 
festivals facilitated socialization and the business in taverns and local shops, institutional or otherwise, marketing the local agricultural products (wine, olive oil, fruit and sausages). In this line of reasoning, is it not surprising that in 1912 more than $60 \%$ of annual expenditure with the festivities were allocated to the profane elements (fireworks, decoration and lighting), while only $18.5 \%$ of financial resources were intended for the religious arrangements ("Despesas da Irmandade Senhor Afflicção", Arquivo Distrital Viseu, cx. 2185, $\mathrm{n}^{\mathrm{0}}$ 13). Thus the profane dimension increased, with social and even economic events being added to the festivities, such as the "Annual cattle fair" in the 1930s, and traditional games and football matches. Music, in turn, is another unquestionable dimension of these festivities, with brass bands brightening all events, religious or recreational, creating an atmosphere conducive to socialization.

These events stimulated the parish, a situation which remained unchanged until the early 1970s. When the wine making business was unpromising, as was the case during the world conflicts, the budget for fireworks and bands was tighter. Meanwhile, the open fair, football matches and other activities were suspended, and musical groups performed in addition to brass bands. The Senhor da Aflição festivities continued to be the highlight of the parish, opening opportunities for social contacts, economic activities, and maintenance work on buildings and in the surrounding landscape.

Today, the profane and social dimensions, and especially the recreational aspect attract everyone alike, but especially the younger population and the non-residents. In this context, while the recreational and musical aspects were prominent in 2013, spending on brass bands, in particular the "Banda Marcial de Cambres", diminished as the investments are made mostly in evening concerts. Three processions are still held (Photos 3 and 4), in addition to solemn masses, the brass band, "gigantões", sports activities linked to Sporting Clube de Cambres (local sports club), the local market and street vending is also boosted, as the Cambre-born individuals living in other urban centres and emigrants who participate in these festivities bring their friends, which helps revitalize the parish. 
Photo 3 - The festivities of Senhor da Aflição: the brass band.

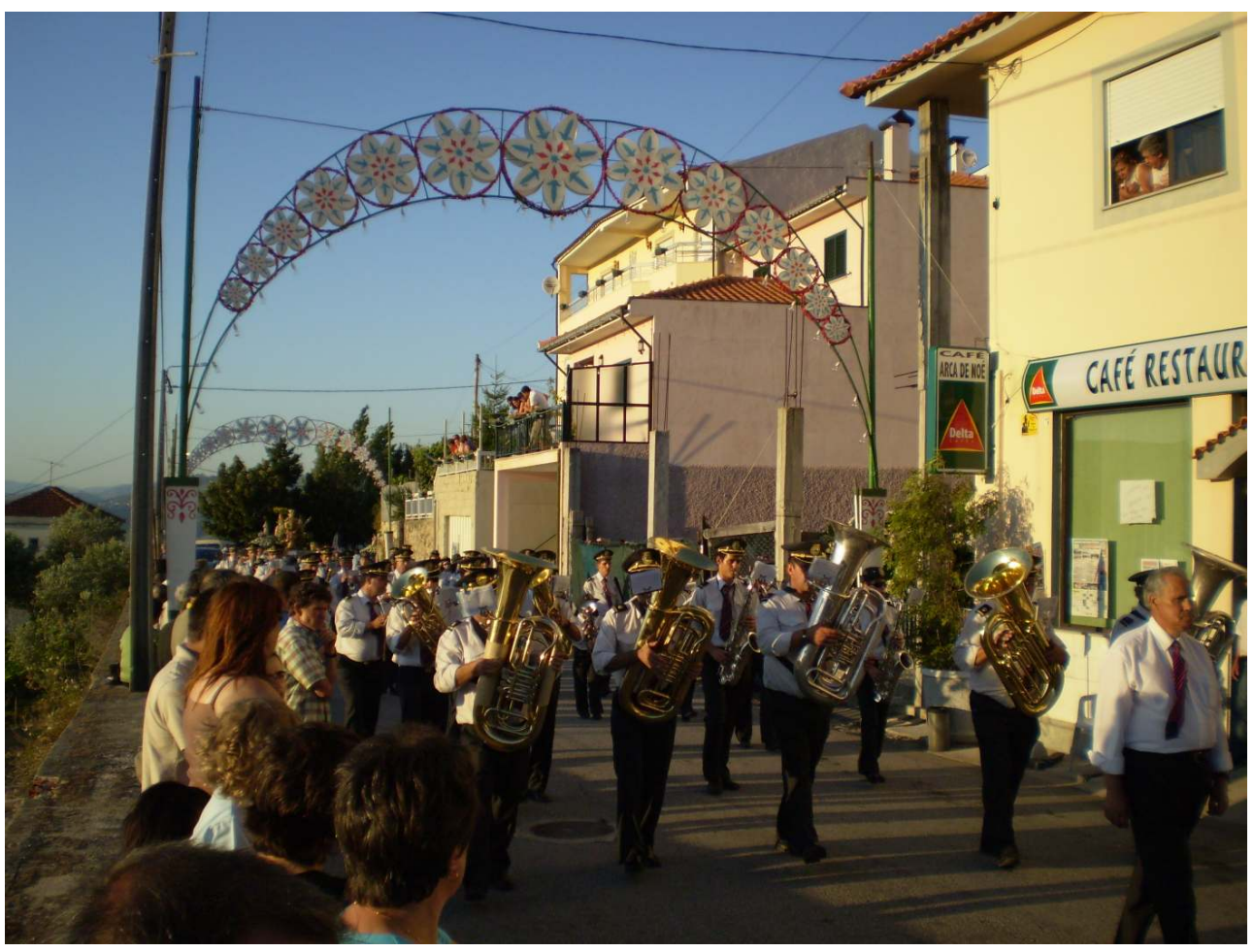

(Photo of author, Cambres July, 2013)

Photo 4 - Procession of Senhor da Aflição.

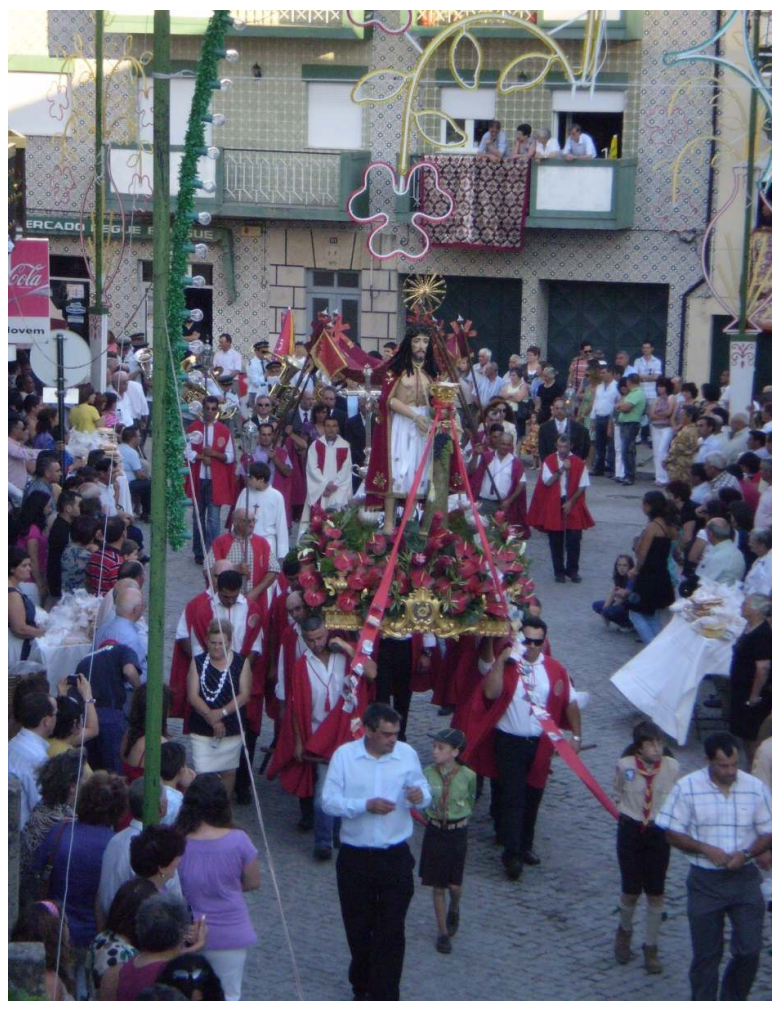

(Photo of author, Cambres, July, 2013) 
Moreover, the social impact throughout the year is very positive, in particular with auctions and the collection of products to be auctioned. These festivities are nevertheless under threat, as they require considerable amounts of money and work, even though the older residents are the ones that invest more in the organisation and continuity of the events. Due to the increasing apathy and lack of human and financial resources, the architectural heritage is deteriorating and traditions and distinctive local specificities are being lost, hindering the sustainable development of this parish.

\section{Santa Eufémia (Saint Euphemia) festivities and local development}

\section{Some background notes}

Still in the Lamego council (NE Portugal), on the left bank of the Douro River but heading about $20 \mathrm{~km}$ East, we come to the small parish of Parada do Bispo, with about $2 \mathrm{~km}^{2}$. Like Cambres, Parada do Bispo is part of the DDR and its landscape is quite attractive, with the recently restructured and mechanized vineyards (Photos 5 and 6). Though traditional vineyards are still found in the smaller family-owned farms, they are fewer in number. The vineyards are planted on schist soils, which is great for obtaining better quality wines. To reach them, however, the roads are well preserved but very narrow and winding, making mobility difficult. The history of this parish is directly linked to the Diocese of Lamego, as one of its farms was located here, producing good quality wines and some olive oil. The farm spread on the slopes from the margins of the Douro River to Valdigem, a neighbouring parish, totalling 100 hectares in size. When the church's assets were confiscated, which was common in Europe, this farm was sold in 1864 to the family who still owns it, although the family has now branched out in two.

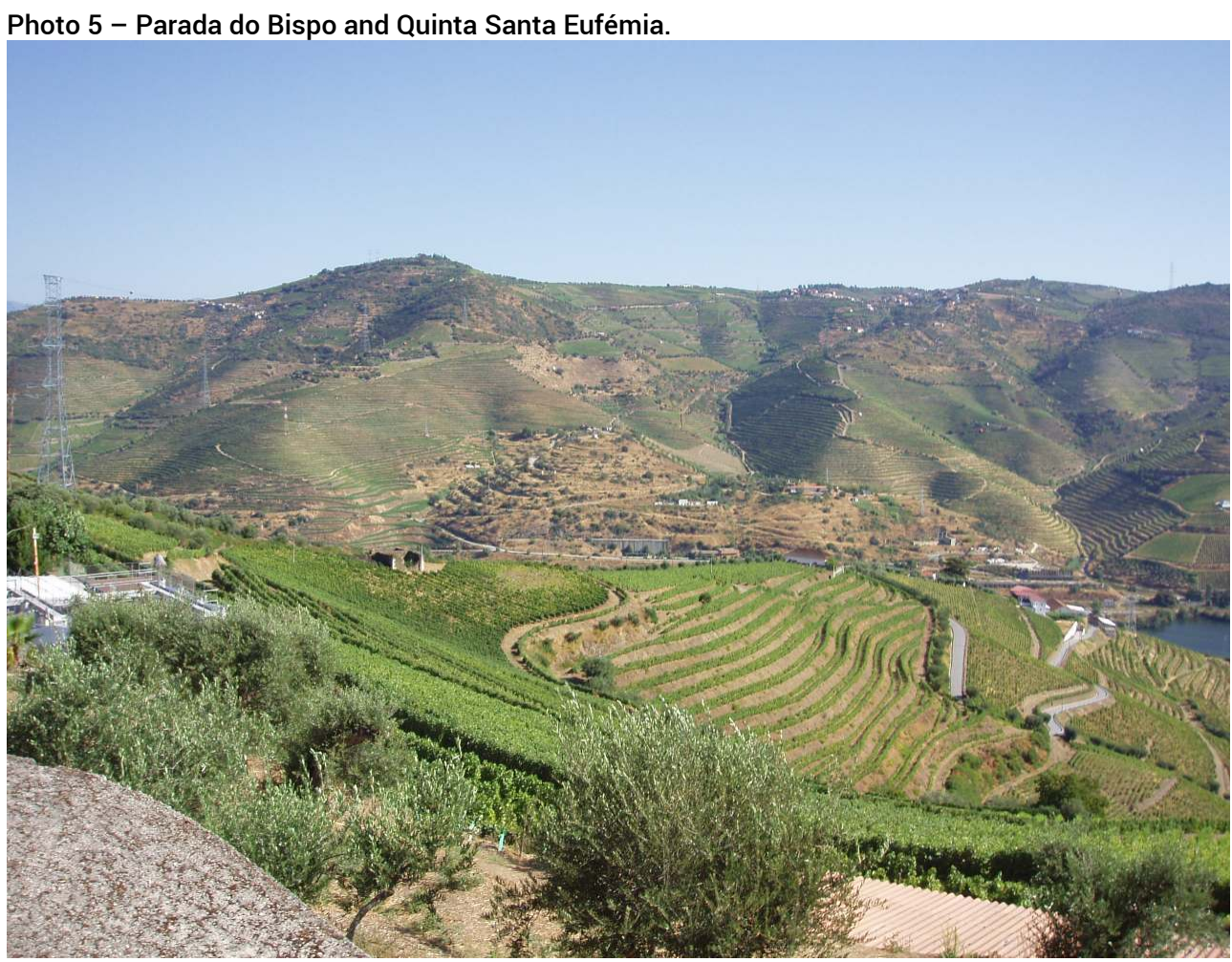

(photo of the author, Parada do Bispo, August 2013) 
Photo 6 - House of Quinta da Santa Eufémia, border to the chapel.

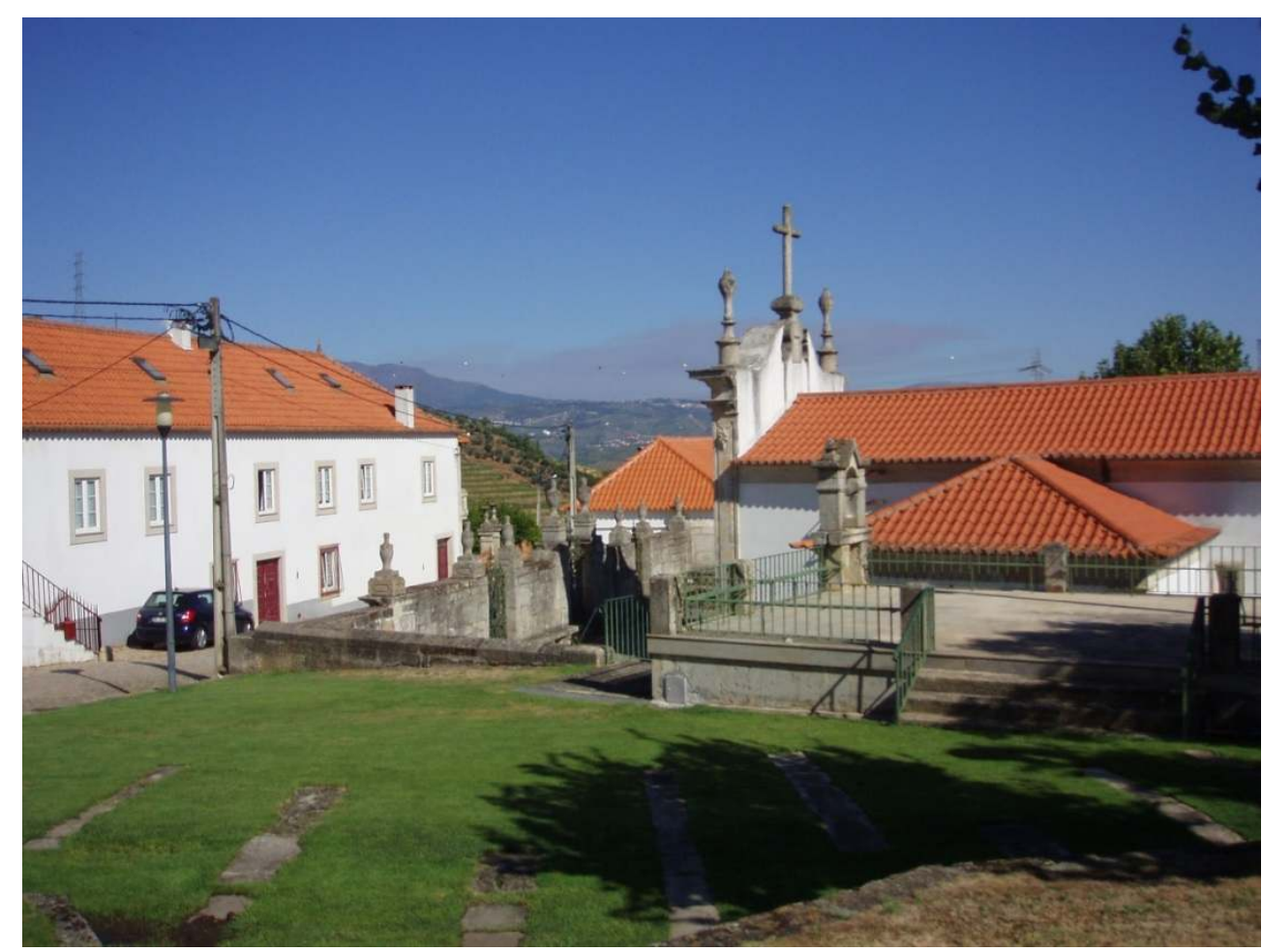

(PHOTOS OF THE AUTHOR, PARADA DO BISPO, AUgUST 2013)

The parish was donated by king Afonso Henriques to the Bishop of Lamego, D. Mendo (COSTA, 1992). Set in a stunning landscape, "overlooking" the Douro River, the estate housed one of the church's houses and a chapel in honour of Santa Eufémia, from whom the estate takes its name. This well-known estate faced some problems in the $19^{\text {th }}$ century, when the vineyards were totally destroyed by phylloxera, as shown in various documents (AZEVEDO, s/d).

As Parada do Bispo corresponds to a "barca de passagem de Bagaúste" (one of the many crossings over the Douro River) and the city of Lamego, it was the district capital until the early $19^{\text {th }}$ century. In addition to the ecclesiastical residence, it also boasted a fountain and several Pombaline-style milestones, corresponding to the quality of wines produced there and justifying the expansion of the vineyards in the $18^{\text {th }}$ century.

Despite all these positive aspects, the problems are many, including labour shortage, poor technical qualifications of staff, and demographic decline. Parada do Bispo was not immune to the demographic decline of the region and to the structural aging of its residents - whereas in 1900 there were 217 residents, and 291 in 1950 (peak value), there were only 149 residents in 2011! In the last decade the drop was over $25 \%$, meaning that the resident population corresponds to $51.2 \%$ of the numbers in 1950 ! As in Cambres, this population decline reflects the successive regional wine crises, which led to migratory flows, which is today about $31 \%$ of residents are over the age of 65 , while the younger population has left the parish.

The wine sector, however, supports local economy, yet it is based on a very dichotomous structure, and family-coordinated. In fact, Parada do Bispo is a $2 \mathrm{~km}^{2}$ parish with only 15 farmsteads, mostly wine-growing businesses, with an average size of 11 hectares, in 2009 
(INE). However, only two farms - already mentioned - represent about $90 \%$ of the total area taken up by vines, the predominant culture. Of the remaining 13 farms, 6 of them are not even 1 hectare in size. Although lacking in capital and having a traditional structure, these farms help preserve the area, culture, and landscape, and, ultimately, along with the two larger farms (over 50 hectares) may continue to bear the classification given to the DDR by UNESCO.

Tradition and innovation co-exist in this parish, with the two large farms being the greatest innovators by combining the wine industry with Rural Tourism (Casa de Santa Eufémia) or wine tourism. As this is a seasonal activity, it is a strategic investment which, as in Cambres, has boosted the area and benefitted the preservation of landscape, viticulture, and the social structure. Local festivities are another great potential in the area, which is why its impact needs to be studied.

\section{Santa Eufémia festivities and the sustainability of the parish}

The parish honours Santa Eufémia in a festivity held twice a year, the first one on the last Sunday of August (or on the Sunday closest to 6 September), and the second one, with centuries-old roots, on $1^{\text {st }}$ November, called the "marrã" festivity, combining both the religious and the profane dimensions. These festivities were once held in the chapel that once belonged to the estate and is now public property. This sumptuous chapel, especially its high altar, is indeed emblematic of the economic and historical importance of the estate and of the power that the clergy had in the region.

The festivities include several masses on Sunday morning, the last of which is accompanied by the music band, which in fact remains there until the end of the day, playing a major role in the profane celebrations. Keeping with the tradition, the "marrã" meal follows the mass (in 1532, the Lamego "marrã" pork female meat was served in the Portuguese royal court and was also available in a vast territory beyond the borders due to its organoleptic quality - (DIAS, 1947).

Local commerce, however, does not benefit from the insufficient space and location of the chapel, but the population in general takes advantage of the festivities and sets up stalls, grills and tables on both sides of the street leading up to the chapel, as allowed, to sell the "marrã meat" to pilgrims and outsiders. Street vendors selling all kinds of products, but mostly local products (sausages, cheeses, local sweets, handicrafts, etc.) take up their space in the square and near the chapel (Photos 7 and 8).

There have been adjustments to this festivity, all of which in the aftermath of economic events and, indirectly, adapting to the holiday period of those who have emigrated: although the main festivity is held on 1 November, it has been "replicated" on the Sunday closest to 6 September, in order to combine this new festivity with all the other regional events, and to satisfy all those who can only visit the region during this time. The devotion shown to Santa Eufémia is also quite profound. 
Photo 7 - Some images of the busy activities and street commerce.

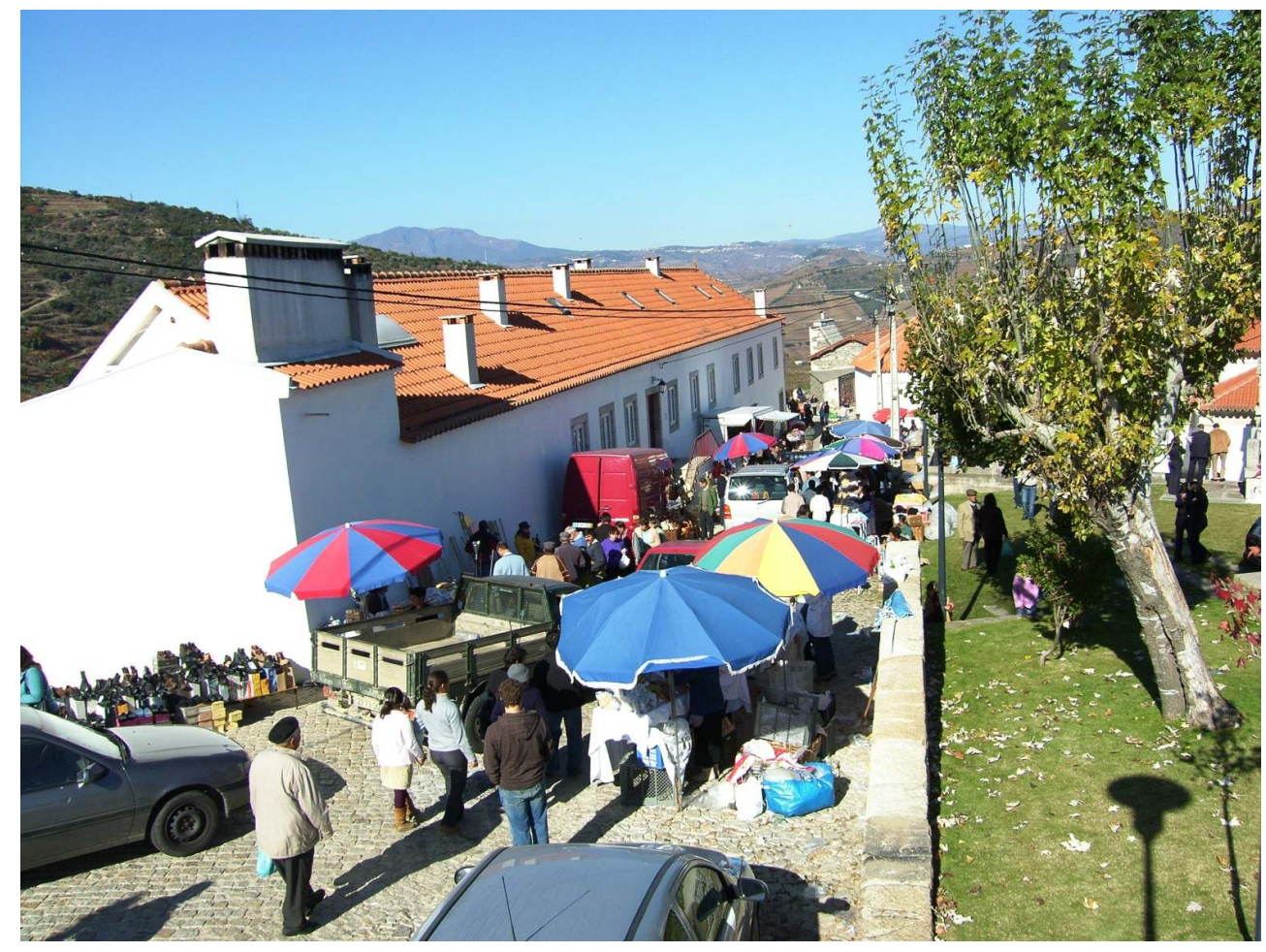

(PHOTOS OF THE AUTHOR, PARADA DO BISPO, AUgUST 2013)

Photo 8 - The brass band.

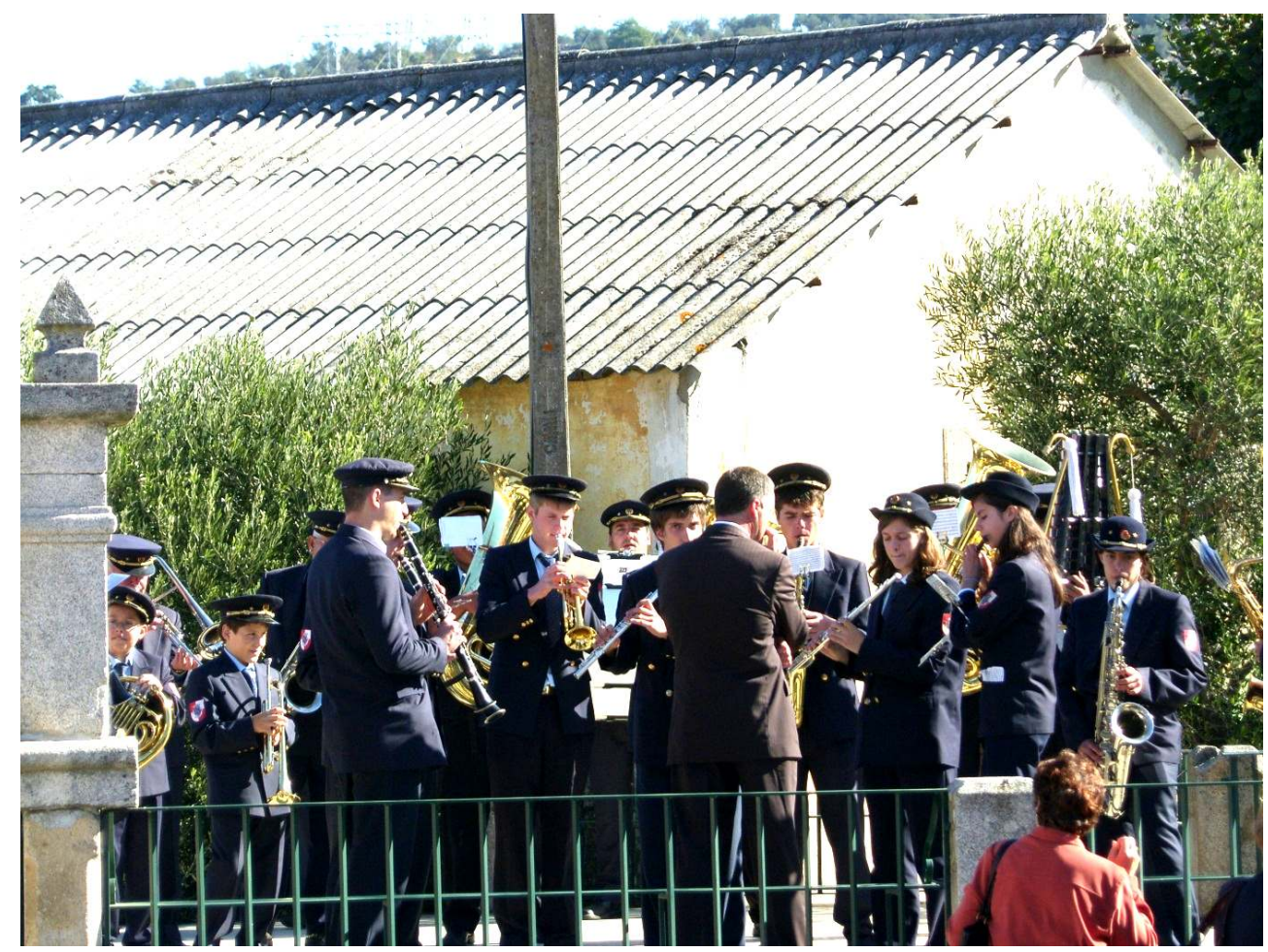

(photo of the author, August 2013) 

organisation of these events require large amounts of money and a lot of work carried out over the entire year. The continuity of these festivities is at stake not only because the old age organisers are increasingly more tired, but also because the festivities interfere negatively on permanent activities such as wine tourism (they have to close down on these days due to poor safety conditions, but especially because of traffic problems). If this does happen, the architectural heritage will deteriorate and local traditions will be lost, which are part of the identity of this people, making the sustainable development of the parish and region more difficult. Regional cultural diversity will also be limited, with fewer cultural events, which would otherwise be preserved and properly coordinated in order to fight against the seasonal nature of tourism and boost the sustainable development of these rural areas.

\section{Some concluding remarks}

51 Although very frail, the rural world has much potential that is not always put to best use, especially when we talk in terms of sustainable development. Although new strategies appear directed at the multifunctional purposes of landscapes, the impact of built 
heritage, and especially intangible heritage, such as festivities and processions is sidelined.

Although these events highlight the religious component, they also include the cultural, social and economic dimension, thereby facilitating the preservation of customs and mores, historical values, built and intangible heritage, bringing in key dynamics to these rural areas. This is a way to uplift not only the territory in which they take place, but also a vaster territory, in an arrangement not limited to the days on which the festivities are held, rather throughout the year, expanding the socialization of residents, contacts with economic agents, and the projection of traditions among the younger social groups, who are now more educated and able to innovate.

Although the festivities in honour of Senhor da Aflição in Cambres parish, or those in honour of Santa Eufémia in Parada do Bispo parish, in Lamego, are outstanding examples, they also face many difficulties. Despite their location in superb settings with good access roads, problems become more complex. To minimise them, efforts are made by investing in the multifunctional uses of the landscape, where tourism stands out, yet other possibilities are ignored, namely its culture, traditions, and mythical aspects. There is an urgent need to develop the local assets, making local and regional agents aware of the need to requalify, preserve, and enhance this heritage, without overlooking the importance of having an attractive marketing in place to strengthen and improve the Douro brand image. These strategies should be implemented in a wide-ranging network approach, but not overshadowing the rural resources, despite the relevance of urban attractions. We must remember that the success and continuity of festivities in a rural environment depends not only on local agents and existing social cohesion, but also on the official, public and private support, and especially support from local governments and the church.

Although investing in the Douro tourism is a strategic move, we can never neglect the wine industry, because this is the economic mainstay of the parish and of the DDR, or its social structure, the individuals who help preserve local heritage. If we include festivities and processions in tourism events, we will also reduce the seasonality of tourism in the region, which is still much concentrated in the harvest period. There should be more activities to complement the existing ones, integrating the surviving festivities and processions in this dynamic, creating, for example, a "Roadmap of Festivities and Processions". In short, we will only be able to revitalize these rural areas in a sustainable way in a cyclical perspective if we involve all actors, in particular the young ones with their entrepreneurial spirit and innovative skills, boosting local resources, focusing on a complementarity between the rural and the urban environment, in network, combining various interests. The dynamics to be found must never underestimate or undervalue the many local assets, like those related with the festivities. After all, it is all about maintaining an area classified by UNESCO as World Heritage! 


\section{BIBLIOGRAPHY}

AZEVEDO, C. O Douro Maravilhoso. s/l, Porto, s/d.

BLUME, R. Land and Rural Affairs: the demystification of the end of the rural, Dissertação de Mestrado, UFRGS, Porto Alegre, pp.182, 2004.

BOTELHO, Maurilio. Desenvolvimento, espaço e crise estrutural, Espaço e Economia [Online], consultado o 12 Novembro 2015. URL : http://espacoeconomia.revues.org/153 ; DOI : 10.4000/ espacoeconomia.153, 2013

CASTRO, Cleber, FORTUNATO, Rafael. Redes populares de turismo e experiências de mapeamento participativo: a atuação da Rede Brasilidade Solidária em Teresópolis (RJ), Revista Continentes (UFRRJ), ano 3, n.5, p. 202-208, 2014

CLAVAL, Paul. Espaço e território: as bifurcações da ciência regional, Espaço e Economia [Online], consultado o 12 Novembro 2015. URL : http://espacoeconomia.revues.org/94 ; DOI : 10.4000/ espacoeconomia.94, 2012

CLOKE, P. Conceptualizing Rurality. Handbook of Rural Studies, Sage Publications, London, 2006. COSTA, M. História do Bispado e Cidade de Lamego - Barroco II. Oficinas Gráficas de Barbosa e Xavier, Lda: Braga, 1992.

DIAS, A. Lamego no final do século XVIII. Edições Beira Douro: Vila Nova de Famalicão, 1957.

FERNANDES, A. O discurso de reinvenção a ruralidade - exigências e representações urbanas na construção de uma ruralidade consumível, in Atas IV Congresso de Estudos Rurais, Universidade de Aveiro, Aveiro, pp. 347-361, 2010.

GPPAA. Plano Nacional de Desenvolvimento Rural 2007-2013, Objetivos estratégicos e princípios orientadores de programação, MADRP, Lisboa, 2005.

KLAUCO, M., WEIS, K., STANKOV, U., ARSENOVIC, D. \& MARKOVIC, V. Ecological significance of land-cover based on interpretation of human-tourism impact. A case from two different protected areas (Slovakia and Serbia). in Carpathian Journal of Earth and Environmental Sciences, vol. 7, n⿳⺈ 3, North University Center of Baia Mare, 2012.

INE. Censos da População (1864 a 2011). Instituto Nacional de Estatística, Lisboa

INE. Recenseamento Agrícola de 1989. Instituto Nacional de Estatística, Lisboa, 1989

INE. Recenseamento Agrícola de 1999. Instituto Nacional de Estatística, Lisboa, 1999

INE. Recenseamento Agrícola de 2009. Instituto Nacional de Estatística, Lisboa, 2009

MARMUREANU, L., GEAMANA, N. \& VADINEANU, A. Methodological aspects of the investigation of complex interaction among people and biodiversity's componentes.), Carpathian Journal of Earth and Environmental Sciences, vol. 6, nํ2, North University Center of Baia Mare, 2011.

MAXWELL, S.; UREY, I.; ASHLEY, C. Emerging Issues in Rural Development, an issues paper, Overseas Development Institute, London, pp.10, 2001.

OLIVEIRA, E. Festividades cíclicas em Portugal., Publicações Dom Quixote: Lisboa, 1984. 
OLIVEIRA, Leandro. et al. Os "limites do crescimento" 40 anos depois: Das "profecias do apocalipse ambiental" ao "futuro comum ecologicamente sustentável", Revista Continentes (UFRRJ), ano 1, n. 1, 2012, p. 25

PINA, Helena. O Alto Douro- um espaço contrastante em mutação, col. Temas Portugueses, Imprensa Nacional Casa da Moeda, Lisboa, 2007.

PINA, Helena. The multi-functionality of the Douro landscapes, one of the strategies for its sustainability. New ruralities and sustainable use of territory. Department of Geography and Spatial Management, University of Saragossa: Spain, p. 405-429, 2009.

PINA, Helena. The tourism and the development of the Douro Region, World Heritage Site. in Actas do $3^{\circ}$ Congresso Internacional "Casa Nobre, um património para o futuro", Universidade do Minho e Câmara Municipal de Arcos de Valdevez, Arcos de Valdevez, 2011.

PINA, Helena. The Douro Region, a heritage to develop and innovate while preserving, Major Issues of the European Space: planning policies and territorial restructuring in European Peripheries, Milena Press, Bucareste, 2012.

PINA, Helena. A estrutura fundiária duriense - um quadro problemático que urge reverter e dinamizar. Direito Rural, org. Glória Teixeira, Vida Económica Editorial S.A., Porto, p. 203-244, 2013.

PINA, Helena. The Douro intangible heritage: what contribution to regional development. in "The Overarching Issues of The European Space - The Territorial Diversity of Opportunities in a Scenario of Crisis / Grandes Problemáticas do Espaço Europeu - Diversidade Territorial e Oportunidades de Desenvolvimento num Cenário de Crise", Universidade do Porto. Faculdade de Letras, 2014.

TERLUIM, I.; STRIJKER, D.; MUNCH, W. 18. Economic Dynamis in Rural regions. in Oskam, A.; Meester, G.; Silvis, H. (Eds) "EU policy for agriculture, food and rural areas", Wageningen Academic Publishers, Wageningen, pp.309-323, 2010.

VALLINA, J. Manual para Agentes de Desarrollo Rural. Ideas y propoestas para moverse entra la conservación del património y el desarrollo local, Ediciones Mundi-Prensa, Madrid, pp. 453, 2002.

VASCONCELOS, J. Etnografia Portuguesa. edição fac-similada. INCM: Lisboa, 1997.

WOODS, M. Rural Geography, Processes, Responses and Experiences in rural Restructuring, SAGE Publications, London, pp. 330, 2005.

Portuguese and regional newspapers

O Primeiro de Janeiro. Julho de 1880: Porto

Jornal da Regoa. Julho de 1880, Peso da Régua

A Semana, Julho 1900 - 1909, Lamego

A Voz de Lamego, 1935-2013

Varanda do Douro, 1950 a 1995, Lamego

Handwritten documents

Livro de Receitas e Despezas. Irmandade de Nosso Senhor da Aflição, Cambres 


\section{ABSTRACTS}

When talking of rural spaces, we usually mean peripheral areas with a range of problems, but whose potential and dynamics for revitalisation are evident. This is the case of the Douro Demarcated Region (DDR), home to an idyllic landscape of countless terraces on slopes laden with vines as well as a unique architectural, human and cultural heritage. Nevertheless, the obstacles to its development escalate, ranging from the environmental and landscape structure to the economic, social and cultural. In this paper, from a wide range of problems afflicting the region, we intend to focus on the cultural component, particularly the intangible one, highlighting the strategic role of the popular festivities and pilgrimages in the rural sustainable development.

Embora repleta de problemas ambientais, econômicos, sociais e culturais, a rica diversidade encontrada no mundo rural possui enorme potencial que carece ser estimulado. É o caso da Região Demarcada do Douro (RDD): parcialmente classificada pela UNESCO como patrimônio mundial, sua paisagem é marcada por uma impressionante força arquitetônica, cultural, social e enológica. Contudo, ela vem sofrendo com o envelhecimento populacional, o baixo dinamismo econômico e o declínio de estruturas sociais, e é exatamente por estes motivos que os recursos locais devem ser preservados e valorizados. Neste contexto assumem destaque as festividades que, embora essencialmente religiosas, são também eventos sociais, culturais, econômicos e turísticos. Assim sendo, elas são cruciais tanto na compreensão mais ampla do passado coletivo quanto na revitalização da região em termos sustentáveis.

En dépit des plusiers problèmes environnementaux, économiques, sociaux et culturels, la diversité du monde rural a un potentielle qui mérite d'être stimulé. C'est le cas de la région démarquée du Douro (RDD) : classifiée partiellement en tant que patrimoine mondial par l'UNESCO, son paysage garde une impressionante force architecturale, culturelle, sociale et oenologique. Cependant, la région souffre à cause de viellissement de la population, le bas dynamisme de l'économie et le déclin des structures sociales, et c'est précisement en fonction de cela que les ressources locaux doivent être préservés et valorisés. Dans ce contexte, on souligne les festivités : de nature essentiellement réligieuse, elles sont aussi des événéments sociaux, culturels, économiques et touristiques. Ainsi, elles sont cruciales soit pour une compréhension plus élargie du passé collective, soit pour révitaliser la région sous l'égide de la sustentabilité.

Cuando abordamos los espacios rurales, habitualmente nos referimos a espacios periféricos y problemáticos, pero donde las potencialidades y las dinámicas para su rehabilitación están presentes. Lo que sucede en la Región Demarcada do Douro (RDD) envuelve un cuadro paisajístico idílico, donde se suceden los viñedos pero también aparece un soberbio patrimonio arquitectónico, humano y cultural. Sin embargo, se presentan muchos obstáculos para su desarrollo, desde los ambientales hasta los paisajísticos, de los económicos a los sociales y aún más los culturales. Este articulo quiere, delante de la multiplicidad de problemas, destacar el componente cultural-inmaterial, con especial incidencia en el posicionamiento estratégico de las fiestas y romerías en el desarrollo de los espacios rurales. 
INDEX

Keywords: rural development, TER, sustainability, intangible heritage, festivities Palabras claves: desarrollo rural, TER, Sustentabilidad, patrimonio inmaterial, festividades.

Palavras-chave: desenvolvimento rural, TER, sustentabilidade, patrimônio imaterial, festividades.

Mots-clés: développement rural, TER, sustentabilité, patrimoine immatériel, festivités.

\section{AUTHOR}

HELENA PINA

CEGOT, Faculty of Arts, University of Porto, Portugal. Email: helenapina@netcabo.pt 